\title{
Nordic Journal of
}

Linguistics

\section{Volume 5}

Number 2

1982

Universitetsforlaget - Oslo 


\section{Contents}

Vol 5. No. 21982

Benny Brodda: Problems with Tagging - and a Solution 93 Liisa Lautamatti: Coherence in Spoken and Written Discourse 117 Jaakko Hintikka: Tag Questions and Grammatical Acceptability 129 John Ole Askedal: Om preposisjonens syntaktiske status i de såkalte atransitive verbalgrupper" i norsk 133

Jorgen Rischel, Review Article: Quantity in Historical Phonology: K. Arnason, Quantity in Historical Phonology. Icelandic and Related Cases 163

Wolfgang Ulrich Wurzel, Rezensionsartikel: Psychologische Realität in der Phonologie: P. Linell, Psychological Reality in Phonology. A Theoretical Study 173

Jonas Löfström, Review of Bente Maegaard \& Hanne Ruus: Hyppige Ord I Danske Romaner, and Hyppige Ord I Danske Borneboger 181

Publications Received 185 


\section{Instructions to Authors}

\section{MANUSCRIPTS}

The normal language of publication is English, but articles in French and German may also be submitted. Authors not writing in their mother-tongue are asked to have their manuscripts checked for errors in language and style.

Articles should in general be as brief as the subject treated allows. All manuscripts must be typewritten with double spacing, on one side of the paper only, using a conventional size of paper, preferably A 4, and with generous left margins. Separate sheets should be used for: 1) Title page, with author's name(s), 2) Abstract, 3) Tables, 4) Figure legends, 5) Notes, 6) References. The original manuscript should be submitted, with two extra copies. The author should retain a copy. Forms in a language not written with the Latin alphabet must be transliterated or transcribed. Whenever possible authors should use standard phonetic transcriptions (preferably IPA) and avoid other signs. Cited forms of the language discussed should be underlined (italics); phonetic representation should be included in square brackets [...], phonemic representation between slant lines /.../, glosses should be added directly after the cited form between single quotes, and reconstructed and nonoccurring (ungrammatical) forms should have an asterisk. If special signs are necessary, the editor should be consulted about the printing possibilities.

\section{ILLUSTRATIONS}

All illustrations and diagrams other than Plates and Tables are to be considered as Figures. Line drawings should be drawn with black India ink, in a size allowing for reduction. Photographs should be unmounted glossy enlargements showing clear details.

\section{ABSTRACTS}

The authors should provide an abstract in English not exceeding 120 words on a separate sheet. The author's name and initial(s), year, title of article, journal title (Nordic Joumal of Linguistics), and volume number should precede the Abstract. Example: Hovdhaugen, E. 1977: Editorial Statement. Nordic Joumal of Linguistics 1, 1-2. The Abstract should be followed by the author's name(s) and the postal adress(es) to which correspondence should be sent.

\section{NOTES}

Notes should be reduced to a minimum and whenever possible incorporated in the text, if necessary in parentheses. Phonetic or phonemic transcriptions should not occur in notes. Notes should be typed with double spacing on separate sheets and numbered consecutively.

\section{REFERENCES}

References to the literature should be incorporated in the text unless they relate specifically to subject matter dealt with within a note. A strictly corresponding reference list should be included at the end of the article. References are the author's responsibility, and the Journal style shown below should be carefully followed to save time and correspondence.

Examples in text: As Bach (1968: 37) and Binnick et al. (1969: 137-198, have shown ...

Several authors (Bach 1970: 37, Bach and Harms 1968: 37-39, Binnick et al. 1969: 137-198) have described...

Reference list (alphabetical, unnumbered): Books: Author's last name, first name, year, colon. Title underlined (italics) and capitalized (doctoral dissertations and unpublished manuscripts should not be in italics.). Publisher, place of publication. Joumals: Author's last name, first name, year, colon. Title of article (capitalized), title of Joumal (underlined and not abbreviated), volume number, page numbers.

Examples:

Chomsky, Noam 1957: Syntactic Structures. Mouton. The Hague.

Jacobs, Roderick A. and Rosenbaum, Peter S. 1970: Readings in English Transformational Grammar. Ginn, Waltham, Massachusetts.

Dahl, Osten 1970: Some Notes on Indefinites. Language 46, 33-41.

Hintikka, Jaakko 1972: The Semantics of Modal Notions and the Indeterminacy of Ontology. In Davidson, Donald and Harman, Gilbert (eds.) 1972: Semantics of Natural Languages. D. Reidel, Dordrecht, pp. 398-414.

\section{PROOFS}

The author will receive one copy of the first proof, which, duly corrected, should be returned to the publisher within the specified time. Authors are requested to check their manuscripts most carefully since corrections in proof are very expensive. The author will be charged for corrections against his/her original text. 